\title{
PROFITABILITY ANALYSIS OF SMALL AND MEDIUM SCALE SALT ENTERPRISES, MISAMIS ORIENTAL, PHILIPPINES
}

\author{
Julieta A. DELOS REYES ${ }^{1 *}$ \\ Abigail T. LAT ${ }^{2}$ \\ Tyrone Jasper I. REODICA ${ }^{3}$ \\ Christine Joy B. MANALO ${ }^{4}$
}

Received: September 2021 | Accepted: November 2021 | Published: December 2021

Please cite this paper as: Delos Reyes, J.A., Lat, A.T., Reodica, T.J.I., \& Manalo, C.J. B. (2021). Profitability Analysis of Small and Medium Scale Salt Enterprises, Misamis Oriental, Philippines, Holistica Journal of Business and Public Administration, Vol. 12, Iss. 3, pp.69-85

\begin{abstract}
The study analyzed the profitability of small and medium scale salt enterprises in Alubijid and El Salvador City, Misamis Oriental, Philippines. It determined salt production practices; assessed the profitability of salt production; and identified the problems encountered in salt production. Fortytwo salt producers in the area were personally interviewed using a pre-tested interview schedule. Descriptive and cost and returns analysis, rate of return on investment (ROI), and ANOVA were employed. Results revealed that the production practices of the salt producers are dictated by the flooring materials of salt beds and the type and volume of salt produced were highly dependent on the flooring materials and on weather. It was concluded that salt production is a profitable enterprise and the salt beds with transparent polyethylene plastic as flooring material were the most profitable, despite having the most labor-intensive production process. Recommendations include usage of transparent polyethylene plastic as flooring material and teaching appropriate technology for seawater filtration to address the problem on degraded quality of seawater with the local government unit (LGU) taking the lead. Also, a soft loan program be put up for buying flooring materials so that more members of the lakeshore community can engage in the salt making.
\end{abstract}

Keywords: Salt production; Profitability analysis; Salt beds flooring

\footnotetext{
1* University of the Philippines Los Baños, College, Batong Malake, Los Baños, Laguna, Philippines, jadelosreyes@up.edu.ph.

2 University of the Philippines Los Baños, College, Batong Malake, Los Baños, Laguna, Philippines, atlat@up.edu.ph.

${ }^{3}$ University of the Philippines Los Baños, College, Batong Malake, Los Baños, Laguna, Philippines, ty.reodica@gmail.com

${ }^{4}$ University of the Philippines Los Baños, College, Batong Malake, Los Baños, Laguna, Philippines, cbmanalo4@up.edu.ph
} 


\section{Introduction}

Salt, chemically referred to as Sodium Chloride ( $\mathrm{NaCl})$, is most commonly used as a food seasoning for human consumption. It does not only provide an essential flavor, but can also intensify aromas, balance other flavors, make meat juicier and preserve food for months or even years (Joachim \& Schloss, 2012). Salt activates the salivary enzyme which helps one's taste bud recognize food and get a headstart on breaking down of food. It also creates hydrochloric acid, a digestive secretion from within the stomach, which aids in digestion and absorption of food (Tata Salt, 2016). Salt plays an important role for human health. It acts as an electrolyte that helps to maintain the fluid balance in the body and helps to regulate the body functions such as heart rate, digestion, respiration, brain activity and blood pressure (Palsdottir, 2017).

Consuming too little salt can be as bad as having too much salt (Tribune News Service, 2018). Too little salt can lead to a potentially dangerous condition known as hyponatremia-an extreme loss of sodium that can trigger symptoms ranging from muscle cramps, nausea, vomiting, and dizziness to shock, coma, and possibly death (Lehman, 2018). On the other hand, too much salt can lead to hypernatremia-an excessive sodium that causes chemical imbalances and negatively affects the brain, kidneys, arteries and heart. High salt intake is linked to increased risk of stroke and cardiovascular disease (Health24, 2019).

Aside from human consumption, salt is also being used in deicing or for melting of ice and preventing its formation; water softener to remove heavy water minerals such as calcium, magnesium, iron and other contaminants for cleaner water at home; for water treatment and saline chlorination in swimming pools (descaling salt); for fertilizers of plants (e.g., coconut) and preservative of fresh fodder such as corn, grasses and legumes (agricultural salt); and industrial salt for chemical, textile, leather and food industries (Infosa, 2013).

Salt has many varieties such as refined table salt which is commonly used for food seasoning; kosher salt which is used by many chefs in professional kitchens to add flavor and remove the surface blood from the meat; sea salt which can also be used for cooking, food processing and other industrial uses; and rock salt or popularly known as the Himalayan pink salt which is widely used for spa treatments and lamps (Iriberri, 2019).

Salt is a naturally occurring substance mostly in areas greatly dominated by seawater. It is harvested either from the sea through evaporation or through mining of salt deposits (Salinas Corporation, 2012). In the Philippines, the traditional practice of making salt requires the flooding of the salt beds with seawater suggesting that salt is normally produced near the shorelines where majority of the fisherfolks live (Yankowski, 2007). It has become increasingly important in the country as evidenced by the fact that in 1990, the country's salt requirement was only 338,000 mt which rose to 590,000 mt in 2009 . In $1990,64 \%$ of said requirement was supplied by local producers and the rest imported from Australia. However, in 2009 , only $28 \%$ was sourced locally and the remaining $72 \%$ 
was imported from Australia and China (Pacific Farms, Inc., 2014). Due to the erratic climate such as prolonged wet season covering the previously hot season and vice versa-prolonged El Niño (the warm phase) and prolonged La Niña (the cold phase)the performance of the salt industry started to decline until it can no longer meet the overall local demand, which gave way to a shift in the livelihood of most salt farmers today (Philippine Chamber of Salt Producers, 2014). This is very alarming because the archipelagic Philippines ranks fifth in the world in terms of the shoreline length and first in the highest coastline-to-land area ratio, a very large amount of resource base for salt production (Pacific Farms, Inc., 2014).

According to the International Trade Center, 20 percent of salt in the Philippines in 2016 was supplied locally and 80 percent or $\$ 24.4$ million worth of salt was imported (Moran, 2018). Despite the shrinking domestic salt industry, the country's demand for salt has intensified with its increasing food and non-food uses. Salt is widely used by Filipino households as well as food processing enterprises in the country. It is also known for its non-food uses such as fertilizer for coconut trees and as medium to activate Sustainable Alternative Lighting (SALt) lamps - a promising Filipino invention that could improve the well-being of the impoverished such as the fisherfolks whose households live with poor lighting in the country's shorelines.

Salt farming in Misamis Oriental, particularly in Alubijid and El Salvador City, is not only viewed as a business but is considered to be a family enterprise by most of its residents. The salt industry is the main source of income of the fisherfolks in the area during dry season. Both men and women are involved in salt-making. Even the children are helping since the solar salt is being produced during summer, the season when children are on vacation from school. Salt is also a community tradition handed down from one generation to another.

Indeed, the salt industry has a substantial role for the country's many and varied industry needs. With low supply of and high demand for salt, the salt industry needs a careful evaluation because it is important to analyze and understand the current situation of salt producers to see where the country has gone wrong and what can be done to improve the current situation. It is also imperative to determine the strengths and weaknesses of the salt industry since increased local production implies reduced importation and therefore foreign exchange savings on the part of the government. The general objective of the study was to analyze the profitability of salt production in Alubijid and El Savador City, Misamis Oriental. The study also aimed to: (1) characterize the salt producers; (2) determine their production practices; (3) assess the profitability of salt production; and (4) evaluate the effect of salt bed flooring materials on the profitability of salt production.

\section{Methodology}

\subsection{Conceptual framework}


HOLISTICA Vol 12, Issue 3, 2021, pp.69-85

Figure 1 shows the conceptual framework used in analyzing the profitability of salt production in the study areas. The salt producers are using three different technologies in the solar evaporation for salt production: brick tiles; black polyethylene plastic; and transparent polyethylene plastic. The flooring materials used dictate the production practices and the costs involved and eventually the net income generated. Net income could also be affected by the revenues generated via the quality of salt produced which dictates the price received for the product.

Figure 1. Conceptual framework used in analyzing the profitability of salt production in Alubijid and El Salvador, Misamis Oriental, Philippines

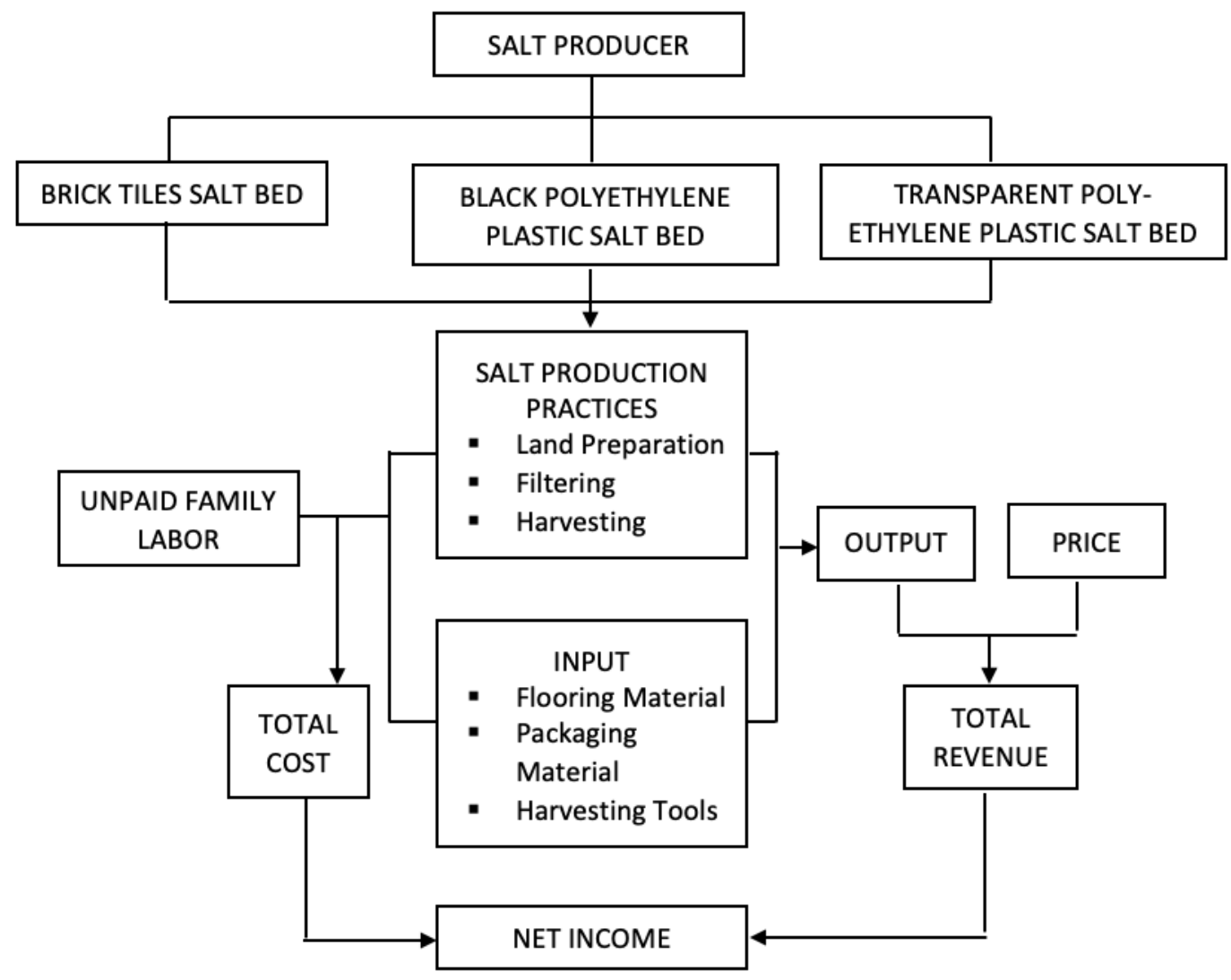

Source: Authors' framework concept

\subsection{Data Collection and Analysis}

All the 42 listed salt producers in Alubijid and El Salvador City in the province of Misamis Oriental were interviewed. Both areas are producing salt through solar evaporation method. The collected primary data include the profile of the respondents such as sex, age, civil status, educational attainment, and number of years in the industry; quantity and prices of salt produced and sold; and production practices. Descriptive and cost and returns analysis and rate of return on investment (ROI) were employed. ANOVA was 
performed to determine if there is a significant difference in the net incomes generated using the different salt bed flooring materials.

\section{Results and Discussion}

\subsection{Profile of the Respondents}

Majority (62\%) of the salt producers were female. The high number of female salt producers may be attributed to the typical regard of women as business managers. Women salt producers are more involved in communicating with the traders and managing the monetary inflow and outflow of the business. On the other hand, men salt producers are more focused on harvesting and hauling of salt which require more energy and strength best suited for males. The average age was 45 years but the highest proportion (21\%) of them are 51 to 55 years old. The youngest was 26 years old while the oldest was 70 years old. This age distribution suggests that the salt industry can be a good source of livelihood no matter what the age may be. Seventy percent of them were married but most mentioned that they were already involved in the salt enterprise even before they got married (Table 1). Salt farming plays a huge part in their lives as it has become a traditional family enterprise that is being passed on from one generation to another.

The largest proportion of the salt producers were high school graduates (31\%) and the least were college graduates (5\%). On the average, they have been engaged in salt farming for 20 years but most (29\%) of them were into producing salt for 16 to 20 years with 1 respondent claiming to have started the business more than 40 years ago (Table 1). Those who have long been engaged in the salt enterprise said that they have inherited it from their grandparents, parents and other relatives and they have retained the business as a source of livelihood.

\subsection{Production Practices}

Although all the salt producers are using the solar evaporation method, they differed in the types of flooring materials for salt beds. Those in El Salvador City use transparent polyethylene plastic (Figure 2) while those in Alubijid use black polyethylene plastic (Figure 3) and brick tiles (Figure 4). The type and volume of salt produced are dependent on the weather conditions and on the flooring material. Large amount of sunlight is required for solar evaporation. As shown in Table 2, overall, 47 percent of the salt producers use black polyethylene plastic while the salt producers who use brick tiles and transparent polyethylene plastic are 17 percent and 36 percent, respectively.

\subsubsection{Alubijid, Misamis Oriental}

The major input used in producing salt is the brine or highly salt-saturated seawater. Figure 5 shows where the brick tiles and black polyethylene plastic are used as salt bed flooring materials in Alubijid, Misamis Oriental. It is mainly composed of four sections, 
HOLISTICA Vol 12, Issue 3, 2021, pp.69-85

namely: (1) water reservoir or imbakan; (2) evaporation compartment or tasikan/paalatan; (3) waterway or salinity measurement compartment; and (4) salt beds.

Table 1. Distribution of 42 salt producers by sociodemographic characteristic, Alubijid and EI Salvador City, Misamis, Oriental, Philippines, 2018

\begin{tabular}{|c|c|c|c|c|c|c|}
\hline \multirow[t]{2}{*}{ CHARACTERISTIC } & \multicolumn{2}{|c|}{$\begin{array}{l}\text { ALUBIJID } \\
(n=27)\end{array}$} & \multicolumn{2}{|c|}{$\begin{array}{l}\text { EL SALVADOR } \\
\qquad(n=15)\end{array}$} & \multicolumn{2}{|c|}{$\begin{array}{l}\text { TOTAL } \\
(n=42)\end{array}$} \\
\hline & No. & $\%$ & No. & $\%$ & No. & $\%$ \\
\hline \multicolumn{7}{|l|}{ SEX } \\
\hline Male & 14 & 48 & 2 & 13 & 16 & 38 \\
\hline Female & 13 & 52 & 13 & 87 & 26 & 62 \\
\hline \multicolumn{7}{|l|}{ AGE (in years) } \\
\hline $26-30$ & 3 & 11 & 2 & 13 & 5 & 12 \\
\hline $31-35$ & 5 & 19 & 1 & 7 & 6 & 14 \\
\hline $36-40$ & 3 & 11 & 2 & 13 & 5 & 12 \\
\hline $41-45$ & 3 & 11 & - & - & 3 & 7 \\
\hline $46-50$ & 5 & 19 & 2 & 13 & 7 & 17 \\
\hline $51-55$ & 4 & 14 & 5 & 33 & 9 & 21 \\
\hline $56-60$ & 1 & 4 & 1 & 7 & 2 & 5 \\
\hline$>60$ & 3 & 11 & 2 & 13 & 5 & 12 \\
\hline Average (in years) & & & & & & \\
\hline \multicolumn{7}{|l|}{ CIVIL STATUS } \\
\hline Single & 6 & 22 & 3 & 20 & 9 & 21 \\
\hline Married & 18 & 67 & 11 & 73 & 29 & 70 \\
\hline Widowed & 3 & 11 & - & - & 3 & 7 \\
\hline Separated & 0 & 0 & 1 & 7 & 1 & 2 \\
\hline \multicolumn{7}{|c|}{ EDUCATIONAL ATTAINMENT } \\
\hline $\begin{array}{l}\text { Elementary } \\
\text { Level }\end{array}$ & 4 & 15 & 1 & 7 & 5 & 12 \\
\hline $\begin{array}{l}\text { Elementary } \\
\text { graduate }\end{array}$ & 7 & 26 & 5 & 33 & 12 & 28 \\
\hline
\end{tabular}


HOLISTICA Vol 12, Issue 3, 2021, pp. 69-85

High school

Level

High school

graduate

College Level

College

graduate
26

22

4

7
7

13

2

5

2

1

7

1

7

3

7

\section{SALT FARMING EXPERIENCE}

$\begin{array}{lcccccc}\leq 5 & 2 & 7 & 1 & 7 & 3 & 7 \\ 6-10 & 7 & 26 & 2 & 13 & 9 & 22 \\ 11-15 & 1 & 4 & 2 & 13 & 3 & 7 \\ 16-20 & 9 & 33 & 3 & 20 & 12 & 29 \\ 21-25 & 2 & 7 & 1 & 7 & 3 & 7 \\ 26-30 & 3 & 11 & 3 & 20 & 6 & 14 \\ 31-35 & 1 & 5 & 2 & 13 & 3 & 7 \\ >35 & 2 & 7 & 1 & 7 & 3 & 7 \\ \text { AVERAGE } & & 19 & & & 22 & \end{array}$

Source of raw data: Authors' survey data, 2018

Figure 2. Transparent polyethylene plastic as as flooring material

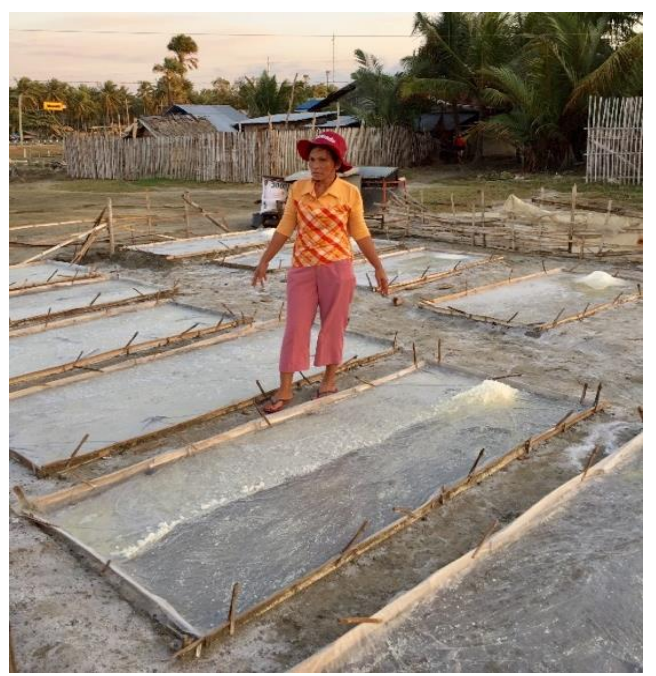

Source: Authors' capture, 2018.
Figure 3. Black polyethylene plastic flooring material

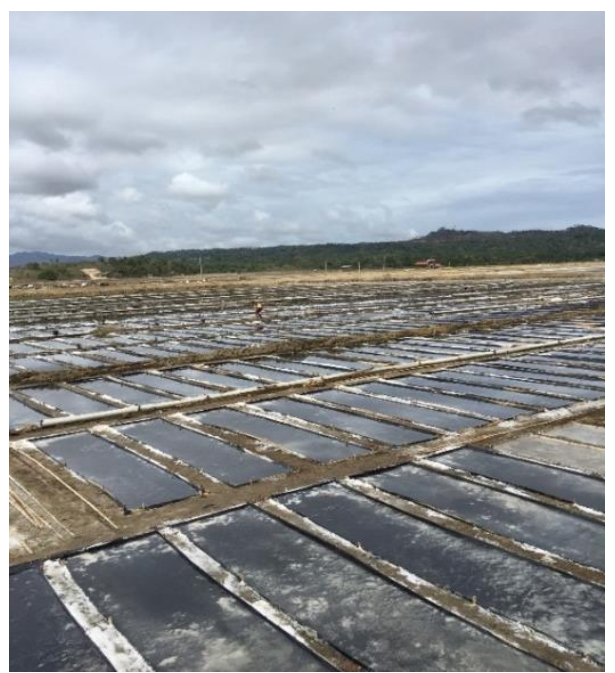

Source: Authors' capture, 2018. 
Figure 4. Brick tiles as flooring material

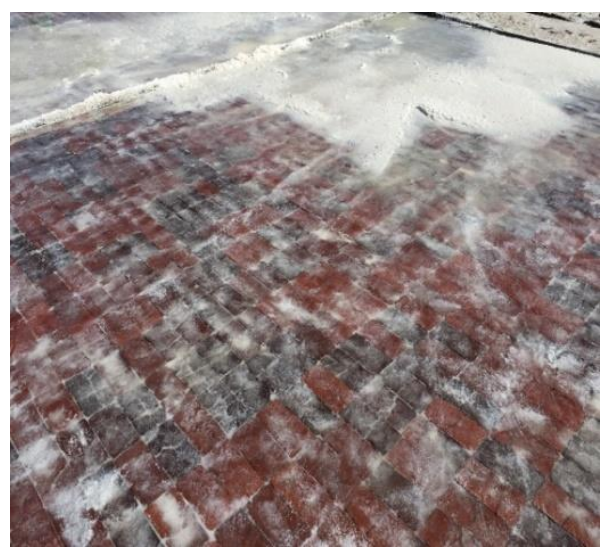

Source: Authors' capture, 2018.

Table 2. Distribution of 42 salt producers by type of salt bed flooring material, Alubijid and El Salvador, Misamis Oriental, Philippines, 2018

\begin{tabular}{lcccccc}
\hline \multirow{2}{*}{$\begin{array}{c}\text { TYPE OF SALT BED } \\
\text { FLOORING MATERIAL }\end{array}$} & \multicolumn{2}{c}{ ALUBIJID } & \multicolumn{2}{c}{$\begin{array}{c}\text { EL SALVADOR } \\
\text { CITY }\end{array}$} & \multicolumn{1}{c}{ TOTAL } \\
\cline { 2 - 7 } & No. & $\%$ & No. & $\%$ & No. & $\%$ \\
\hline Brick Tiles & 7 & 26 & - & - & 7 & 17 \\
Black Polyethylene Plastic & 20 & 74 & - & - & 20 & 47 \\
$\begin{array}{l}\text { Transparent Polyethylene } \\
\text { Plastic }\end{array}$ & - & - & 15 & 100 & 15 & 36 \\
\hline TOTAL & 27 & 100 & 15 & 100 & 42 & 100 \\
\hline
\end{tabular}

Source of raw data: Authors' survey, 2018

The water reservoir or imbakan is where the seawater is stored. An electric water pump is used to suction water from the sea and deliver it to the water reservoir which also serves as fishponds during rainy season, when salt production is not done. The water reservoir has a total land area of 12 hectares divided into 12 fishponds of a hectare each (Figure 5). From the seawater reservoir the brine is transferred into the evaporation compartment or what is locally called tasikan/paalatan, again using water pump. The compartment is further sub-compartmentalized into three with each measuring about one hectare and filled with varying amounts of seawater. The first compartment has a 3inch depth while the second and third compartments have 2-inch and 1-inch water levels, respectively. The flow of the seawater from one evaporation compartment to another takes a day via polyvinyl chloride (PVC) pipe. This means that all the evaporation compartments are flooded within three consecutive days. The main function of the 
HOLISTICA Vol 12, Issue 3, 2021, pp. 69-85

evaporation compartment (also called salinity measurement compartment) is to intensify the salinity.

Figure 5. Solar Evaporation Method using brick tiles and black polyethylene plastic as flooring material

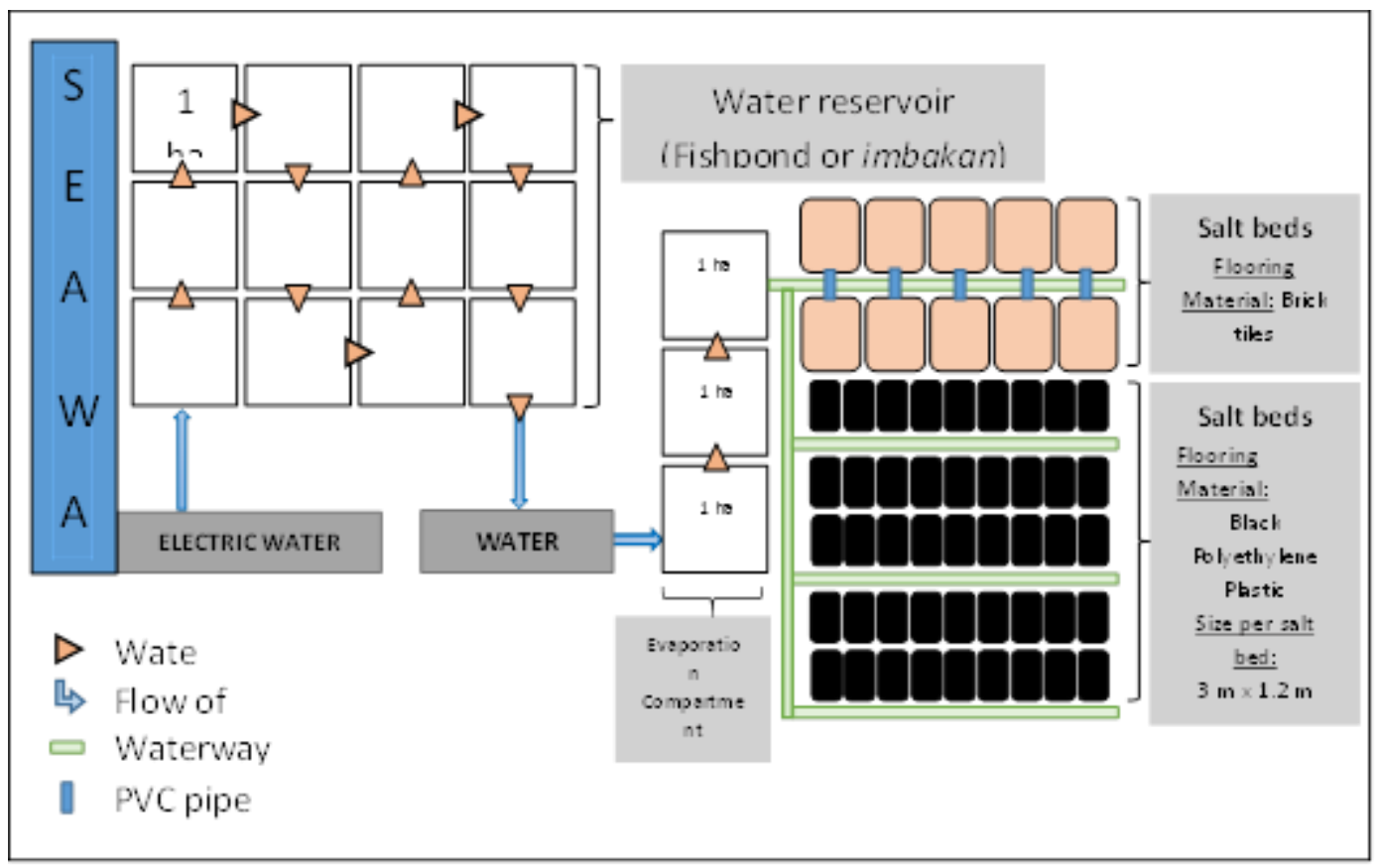

Source: Authors' representation, 2018.

Figure 6. Harvesting of salt using long-handled wooden scraper in the salt bed made of brick tiles

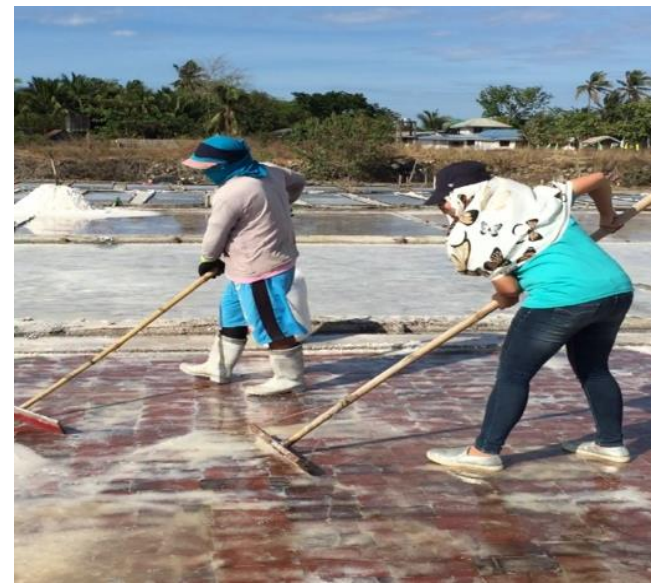

Source: Authors' capture, 2018.
Figure 7. Harvesting of salt using long handled brush in the salt bed made of black polyethylene plastic

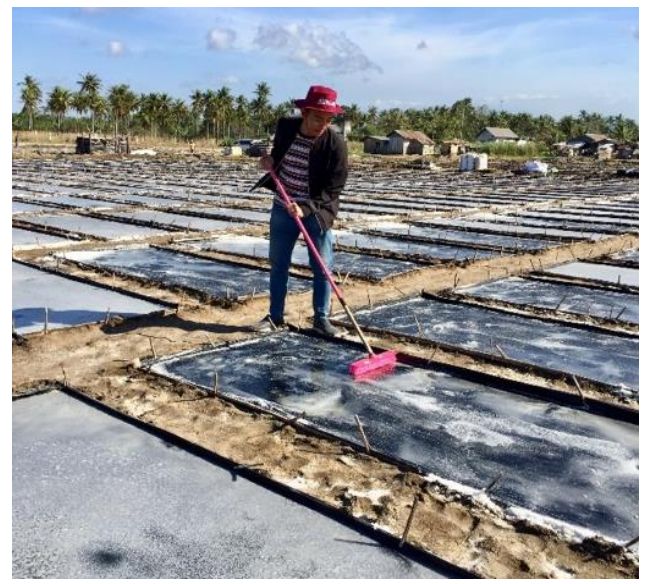

Source: Authors' capture, 2018. 
HOLISTICA Vol 12, Issue 3, 2021, pp.69-85

The seawater would directly flow towards the salt beds made of brick tiles through PVC pipes but dippers or pails are used to transfer the seawater from the waterway to the salt beds made of black polyethylene plastic (Figure 5). This is being practiced daily during dry season at around 5:00 to 6:00 o'clock in the morning. By 3:00 to 4:00 o'clock in the afternoon, when the seawater shall have been formed into salt crystals under the heat of the sun, harvesting of salt is done by scraping the salt beds using long-handled wooden scraper for the salt beds made of brick tiles (Figure 6) and long-handled brush for the salt beds made of black polyethylene plastic (Figure 7).

\subsubsection{El Salvador City, Misamis Oriental}

Figure 8 shows that the solar evaporation method practiced in El Salvador is slightly different. For one, transparent polyethylene plastic is being used as salt bed flooring material. Similarly, the whole production area is composed of four sections, namely: (1) water reservoir or imbakan; (2) filtration or semanya; (3) salinity measurement compartment or istakan; and (4) salt beds. However, only two water reservoirs or imbakan are used by the salt producers. The water stored in the fishpond (first water reservoir) with an area of $500 \mathrm{~m}^{2}$ comes directly from the sea and continuously flows towards the well or balon (second water reservoir) through the PVC pipe connecting the two water reservoirs (Figure 8).

Figure 8. Solar Evaporation Method using transparent polyethylene plastic as flooring material

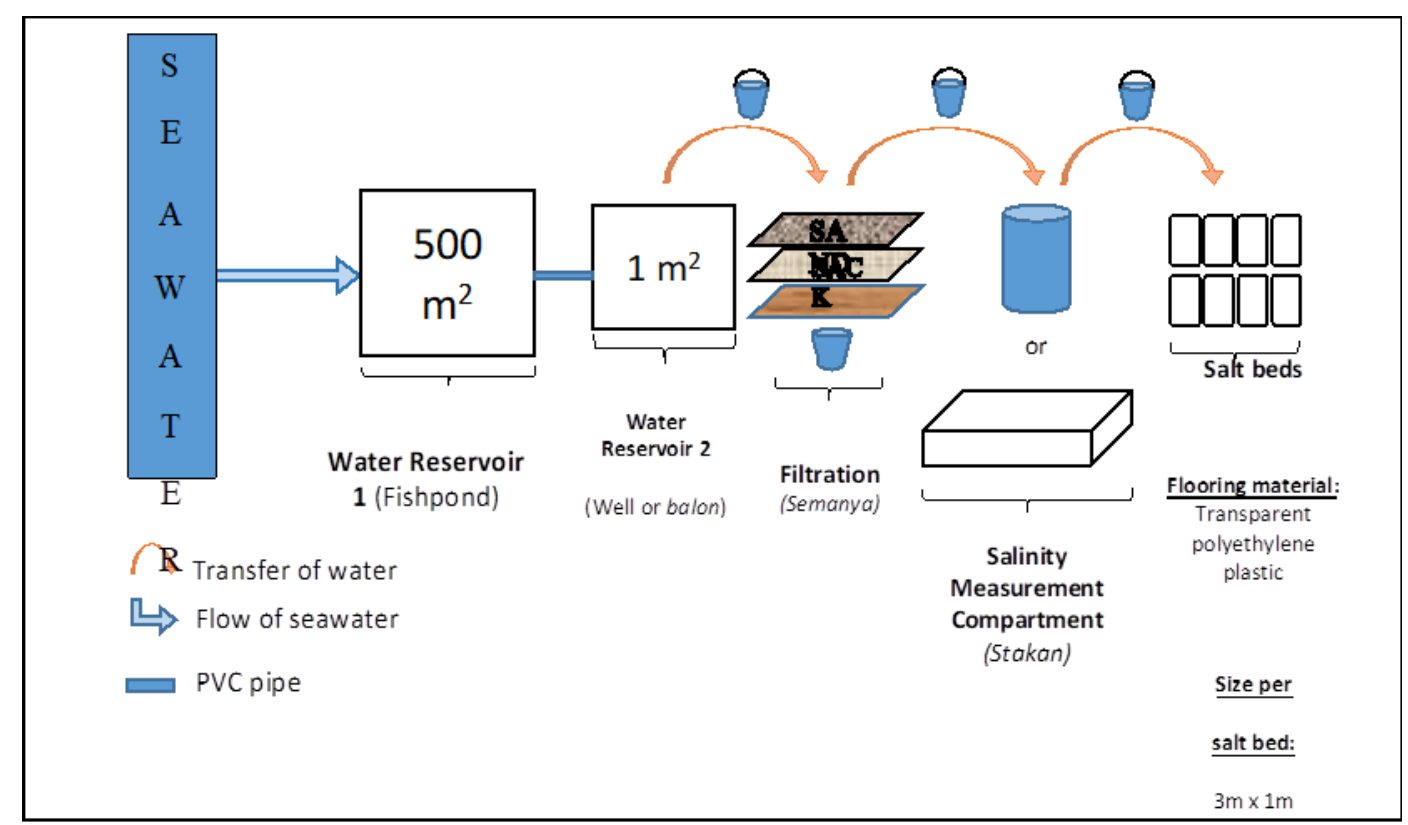

Source: Authors' representation, 2018

Unlike in Alubijid, the production practices done by the salt producers in El Salvador City are more labor-intensive. That is, before the seawater reaches the water measurement 
HOLISTICA Vol 12, Issue 3, 2021, pp. 69-85

compartment (istakan), it is being filtered in a semanya or a set-up of stack of sand, sack, and bamboo slats (Figure 9). The sand used in semanya is collected from the seashore by first plowing using a farm implement locally called paragos (Figure 10). The sand plowing is usually done in the morning for half an hour but the transferring of the plowed sand to the semanya is done in the afternoon for about an hour. Afterwards, they pour the reserved seawater from the well or balon (second water reservoir) using a pail to the semanya for filtration. A pail or basin serves as filtered water receiver underneath the semanya. Once filtered, water is transferred to the istakan (reservoir), which could either be a water storage drum made of plastic or a box made of bamboo lined with clear plastic, and finally to the last destination, the salt beds. This process of salt production produces purer and whiter salt crystals.

Harvesting is done at around 5:00 o'clock in the afternoon when salt crystals are already visible. Unlike in Alubijid, the salt producers with transparent polyethylene plastic in El Salvador City do not use any type of harvesting tool. They use their bare hands (Figure 11) to harvest which, according to the producer-respondents is a means to prevent breakage of the plastic flooring material. Being plastic, the flooring materials can be used for two production seasons only.

Figure 9. Filtration or semanya

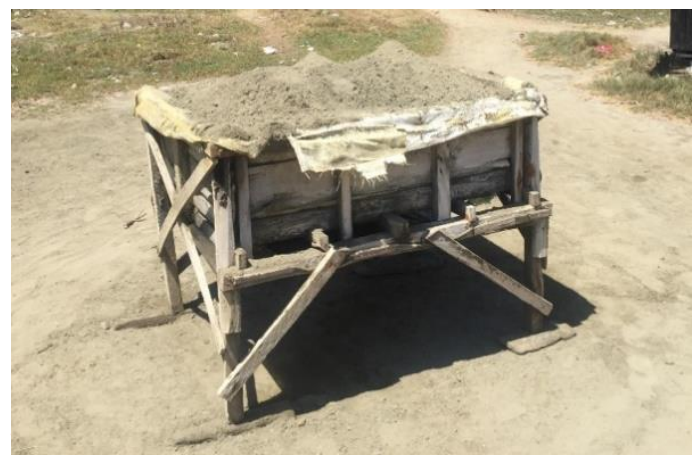

Source: Authors' capture, 2018.
Figure 10. Plow or paragos

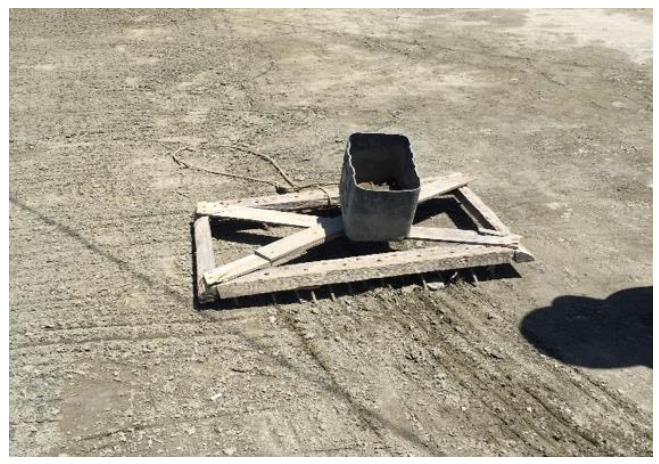

Source: Authors' capture, 2018.

Figure 11. Harvesting of salt using bare hands

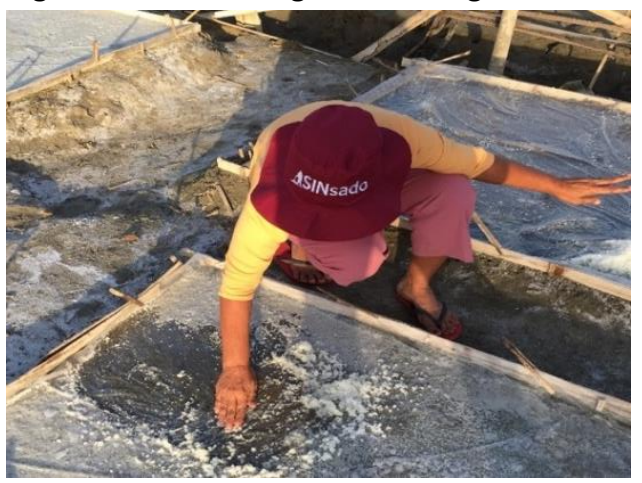

Source: Authors' capture, 2018. 


\subsection{Profitability of Salt Production}

Cost and returns of salt production in Alubijid using brick tiles and black polyethylene plastic as salt bed flooring material and in El Salvador City using transparent polyethylene were computed to determine the net income or profit that they earn per sack of salt (Table 3). Profit was computed by getting the difference between the total returns and total cost. Total returns were computed by multiplying the farm gate price to volume sold. On the other hand, total cost consisted of variable cash costs and noncash costs.

The cash costs included the production cost such as land preparation, land rental and flooring materials (frames made of bamboos, brick tiles and polyethylene plastics); and packaging cost such as sack and straw tie. On the other hand, the non-cash costs included the unpaid family labor and depreciation. Table 7 shows the cost and returns of salt per sack produced in January to May. On the average, one sack of salt using brick tiles and black polyethylene plastic is equivalent to $35 \mathrm{~kg}$. For comparability, all values were converted to $50-\mathrm{kg}$ sack.

The total returns per sack of salt received by the salt producers using brick tiles, black polyethylene plastic and transparent polyethylene plastic were PhP140, PhP360 and PhP480, respectively. As mentioned earlier, the type of salt produced is dependent on the flooring material. The use of brick tiles (Figure 12) produces Class B (semi-white) which is commonly used for food processing such as dried fish and shrimp paste and fish sauce making. On the other hand, the use of black polyethylene plastic (Figure 13) and transparent polyethylene plastic (Figure 14) produces Class A (whitest) which is commonly used as table salt and food seasoning.

The land rental shown in Table 7 refers to the share paid per sack by the salt producers to the landowner. The sharing is dependent on the agreement between he landowner and salt producers. The salt beds with brick tiles as flooring material have a 70:30 sharing. The 70 percent share in the gross sales (PhP98) of the salt per sack goes to the landowner as a form of land rental while the 30 percent goes to the salt producer. On the other hand, the sharing of those using black polyethylene plastic salt beds was 50:50 while those using transparent polyethylene plastic agreed on a 10:90 sharing. The 10 percent (PhP48) of the revenue from sold salt per sack goes to the landowner and the 90 percent is kept by the salt producers. It was also reported that the salt producers have no choice but to follow the decision of the landowners on sharing arrangement.

The average net income per sack of the salt producers who use brick tiles as their flooring material was PhP9.28 while it was PhP105.20 and PhP285.30 for those who use black polyethylene plastic and transparent polyethylene plastic, respectively. The wide differences in the average net incomes from using different salt bed flooring materials can be attributed to the quality of the salt produced which command varying prices in the market. In this case, the highest quality and therefore with the highest price (PhP480/50-kg sack) was that produced using transparent polyethylene plastic. Salt produced from brick tiles is classified as Class B only and hence was priced the lowest at 
HOLISTICA Vol 12, Issue 3, 2021, pp. 69-85

PhP140/50-kg sack. Using black polyethylene plastic also produces Class A salt and thus was able to command higher price at PhP360/50-kg sack. It should be noted however, that aside from the difference in flooring materials, the practice of seawater filtration made a positive big difference in quality as it was able to remove many impurities from the seawater. This results to uniform crystal size (texture) and whiter salt output for those in El Salvador City.

Among the cost items, highest amount was paid for the land rental. Those in Alubijid, regardless of the flooring materials, paid the highest amount for land rental. In terms of land preparation, those in El Salvador had to pay the highest cost at PhP53.75 per 50-kg sack. Land preparation, in their case, includes those for filtration which necessitates the plowing of sand for use in buffering of the semanya.

The rate of return on investment (ROI), the profitability measure that evaluates the efficiency of a business by getting the ratio between the profit and the cost of investment, was computed. Engaging in the salt enterprises requires a large initial capital investment for production process mainly for extensive land requirement. The solar evaporation method needs vast unshaded land area for taking advantage of sunlight. In the study areas however, land used are mostly rented, hence the high cost.

Table 3. Cost and returns of salt production per sack ( $50 \mathrm{~kg}$ ), 42 salt producers, January to May, Alubijid and El Salvador City, Misamis Oriental, Philippines, 2018

TYPE OF FLOORING MATERIAL

\begin{tabular}{|c|c|c|c|}
\hline \multirow{3}{*}{ ITEM } & \multicolumn{2}{|c|}{ Alubijid } & El Salvador City \\
\hline & Brick Tiles & $\begin{array}{l}\text { Black } \\
\text { Polyethylene } \\
\text { Plastic }\end{array}$ & $\begin{array}{l}\text { Transparent } \\
\text { Polyethylene Plastic }\end{array}$ \\
\hline & $(n=7)$ & $(n=20)$ & $(n=15)$ \\
\hline
\end{tabular}

RETURNS

Salt Sales

140

360

480

TOTAL RETURNS

140

360

480

CASH COST

Production Cost

Land

Preparation/Filtration

0.04

0.34

53.75

Land Rental

98

180

48

Flooring Materials 
HOLISTICA Vol 12, Issue 3, 2021, pp.69-85

Frame (Bamboo)

Brick Tiles

0.25

Polyethylene Plastic

31.89

Packaging Cost

Sack

6

8

7

Straw tie

0.09

0.06

0.61

NON-CASH COST

Unpaid family labor

22.5

20

40

Depreciation

3.85

8.41

9.41

TOTAL CASH COST

104.37

226.39

145.29

TOTAL NON-CASH COST

26.35

28.41

49.41

TOTAL COST

130.72

254.80

194.70

AVERAGE NET INCOME

9.28

105.20

285.30

Source of raw data: Authors' survey, 2018.

As shown in Table 4, the rate of return on investment (ROI) using transparent polyethylene plastic (146.54\%) is much higher compared with the brick tiles $(7.10 \%)$ and black polyethylene plastic (41.29\%). A positive ROI is desirable but 50 percent or more is preferred (Aragon, et al., 2010). The highest ROI value using transparent polyethylene plastic was generated even though it required the greatest number of fixed investments (storage box or tangkilya, shovel, pail, basin, paragos, flooring materials and frames made of bamboos) because of the highest revenue generated resulting from high price of Class A salt and relatively lower land rental. Conversely, the lowest ROI value using brick tiles was primarily because of high fixed investments (storage box or tangkilya, brush, shovel, pail, basin, electric water pump, water pump, flooring materials and frames made of bamboos) and high land rental, but lowest revenue generated.

One-way ANOVA was used to compare the average net income generated by the salt producers per type of salt bed flooring materials. As shown in Table 5, the average net incomes generated by the salt producers were significantly different at five percent level of confidence confirming the initial findings that using transparent polyethylene plastic generated the highest income and that using brick tiles had the lowest. This was implied by the F-value (32.73) that is greater than the F-critical value (3.24).

Table 4. Average net income and rate of return on investment by group (flooring material), 42 salt producers, Alubijid and El Salvador City, Misamis Oriental, Philippines, 2018

GROUP

COUNT SUM

AVERAGE

VARIANCE

$\mathrm{ROI}(\%)$ 
HOLISTICA Vol 12, Issue 3, 2021, pp. 69-85

(Type of Flooring Material)

\begin{tabular}{lccccc}
\hline Brick tiles & 7 & 66.64 & 9.28 & 59.61 & 7.10 \\
Black Polyethylene Plastic & 20 & 2152.77 & 105.2 & 4374.46 & 41.29 \\
$\begin{array}{l}\text { Transparent Polyethylene } \\
\text { Plastic }\end{array}$ & 15 & 4315.49 & 285.3 & 13490.1 & 146.54 \\
\hline
\end{tabular}

Source of raw data: Authors' survey, 2018.

Table 5. Results of ANOVA comparing the average net income of the three salt bed materials. 42 salt producers, Alubijid and El Salavador City, Misamis Oriental, Philippines, 2018

\begin{tabular}{llllll}
\hline Source of Variation & SS & df & MS & F-value & F-crit \\
\hline Between Groups & 457133.92 & 2 & 228566. & $32.73^{* *}$ & 3.24 \\
Within Groups & 272333.70 & 39 & 6982.91 & & \\
\hline Total & 729467.63 & 41 & & & \\
\hline
\end{tabular}

**significant at $5 \%$ level of probability

Source of raw data: Authors' survey, 2018

\subsection{Challenges and Problems Encountered}

Foremost among the problems encountered by the salt producers is their heavy dependence on season as they are only able to produce during the dry months. Their problem is aggravated by the fact that it is becoming more and more difficult for them to predict the dry season because of climate change. Seawater quality is another serious challenge because it directly affects the quality of salt produced. While those in El Salvador were able to address the quality challenge through filtration, they are however, beset by the problem of lack of steady market for their high-quality salt because it is more expensive. For those using brick tiles and black polyethylene plastic, the major concern is the very high land rental that eats up a major part of the revenues they generated.

\subsection{Conclusions and Recommendations}

Based on the profitability analysis, it was concluded that salt production in the study areas is generally profitable and a good source of livelihood among the salt producers. The salt beds with transparent polyethylene plastic as flooring material were proven to be the most profitable, despite being the most labor-intensive production process. On 
the other hand, the least profitable was salt beds with brick tiles as flooring material. This is primarily because of the high share ( $70 \%$ as land rental) of the landowner. Based on the interviews with the salt producers who used brick tiles, they would be more encouraged to engage in the salt production enterprise if the sharing arrangement with the landowner would be fair like the sharing arrangement on the black polyethylene plastic.

It is also highly recommended that the salt producers be encouraged to use the transparent polyethylene plastic as flooring material and that concurrently, they be taught the appropriate technology for seawater filtration. Filtration will address the problem on the degraded quality of seawater which affects the quality of salt crystals. The local government unit (LGU) should take the lead in this endeavor in collaboration with experts from the academe for technology generation and dissemination. Also, it is suggested that a soft loan program be put up by the LGU for the purchase of flooring materials so that more members of the lakeshore community can be encouraged to engage in the salt making business. There is also a need for the Department of Trade Industry (DTI) to help the salt producers to market their products in more innovative ways. Marketing tie-ups with industrial users of salt can be initiated through the help of the DTI and the existing association of salt producers in the province of Misamis Oriental. The possibility of salt value addition should also be looked into. To address the issue of seasonality of production, the LGU in collaboration with the association should try to study the adaptability of the cooking method of salt production, which is currently being practiced in Infanta, Pangasinan (Barba, et al., 2018). While this technology is still far from being perfect, best practices can be carefully studied and improved on. Technology benchmarking studies in known salt producing/exporting countries in the world would help a lot in this endeavor.

\section{References}

Aragon, C.T., Quilloy, A.J.A., Catelo, S.P., Delos Reyes, J.A., Manilay, A.A., Elauria, M.M. and Quicoy, C.B. (2010). Farm Management: Approaches and Tools in a Changing Environment. University of the Philippines Los Baños

Barba, M.J., Delos Reyes, J.A. and Lat, A.T. (2018). Profitability of Salt lodization in Selected Towns in Pangasinan, Philippines. Paper presented at the International Society for Southeast Asian Agricultural Sciences 2018 International Congress and General Meeting, Riverside Majestic Hotel, Kuching, Sarawak, Malaysia October 12-14, 2018

Chamber of Salt Producers. Local Salt Production: Proposed Inclusion in the Annual Investments Priority Plan (IPP). Accessed on May 15, 2020 from http://www.mapabcdf.com.ph/documents

presentations/Agribusiness/Agricultural\%20Activities\%20and\%20Services/06\%20Local \%20Salt\%20Production\%20IPP\%20for\%20BOI.pdf

Health24. Why Too Much Salt is Bad for You? Accessed on May 22, 2020 from https://www.health24.com/Lifestyle/Healthy-you/7-reasons-why-too-much-salt-is-badfor-you-20180215

Hills, J., Wood, F., and Ralston, R. Salt: Sodium Chloride. Encyclopaedia Briannica. Accessed on March 22, 2020 from https://www.britannica.com/science/salt 
HOLISTICA Vol 12, Issue 3, 2021, pp. 69-85

Infosa. Applications and Uses of Different Types of Salts. Accessed on July 19, 2020 from http://www.infosa.com/en/salt/applications\#.XOD-m8gzZPY

Iriberri, K. Salt 101: All You Need to Know About Salt. Accessed on July 19, 2020 from https://www.pepper.ph/salt-101/

Joachim, D. \& Schloss, A. (2012). The Science of Salt. Fine Cooking. Accessed on July 19, 2020 from https://www.finecooking.com/article/the-science-of-salt

Lehman, S. Can Consuming Too Little Sodium Cause Problems? Verywell Fit. Accessed on July 19, 2020 from https://www.verywellfit.com/what-happens-if-i-dont-consume-enoughsodium-2507757

National Academies of Sciences, Engineering and Medicine (NASEM). (2019). Sodium and potassium dietary reference intake values updated in new report; introduces new category for sodium based on chronic disease risk reduction. Accessed on July 19,n2020 from http://www8.nationalacademies.org/onpinews/newsitem.aspx?RecordID $=25353$

Nutrition Center of the Philippines (NCP). A survey of salt importers, producers and traders in the Philippines: An evaluation of internal and external quality assurance and control. Accessed on March 12, 2020 from http://www.ncp.org.ph/uploads/4/5/5/3/45531383/ncp-2010-salt_surveyfinal_report.pdf. 62p

Pacific Farms. Philippine Salt Industry. Retrieved from http://www.map-abcdf.com.ph/doc uments/presentations/Agribusiness/Agricultural\%20Activities\%20and\%20Services/06\%2 OPhilippine\%20Salt\%20Industry.pdf

Palsdottir, H.. Salt: Good or bad? Healthline. Accessed on March 18, 2020 from https://www.healthline.com/nutrition/salt-good-or-bad

Philippine Statistics Authority (PSA). Farmers, Fishermen and Children consistently posted the highest poverty incidence among basic sectors - PSA. Accessed on March 18, 2020 from https://psa.gov.ph/content/farmers-fishermen-and-children-consistentlyposted-highest-poverty-incidence-among-basic

Salinas Corporation. The Salt Technology Company. Accessed om March 20, 2020 from http://www.salinas.com.ph/

Tata Salt. Importance of Salt in Our Day-to-Day Life. Accessed on March 20, 2020 from http://tatasalt.com/blog-detail/importance-of-salt-in-our-day-to-day-life

Tribune News Service. Why Eating Too Little Salt is Bad for Your Health, and How Salt Took the Blame for Processed Foods. South China Morning Post. Accessed June 12, 2021 from https://www.scmp.com/lifestyle/health-beauty/article/2123109/why-eating-too-littlesalt-bad-your-health-and-how-salt-took

Yankowski, A. Asinan: Documenting Bohol's Traditional Method of Salt Production and the Importance of Salt in the Region's Early Economy. Accessed June 12, 2021 from https://www.jstor.org/stable/29792608?seq=1\#page_scan_tab_contents

\section{Acknowledgement}

The authors would like to express their gratitude to the Commission on Higher of the Philippines for funding the implementation of the research project entitled "Value Chain Upgrading and Capacity Building of Salt Supply Chain Actors and Business Model Development for Village-level Processors in the Philippines," from data used for this material have been obtained. 